\title{
Seasonal nitrogen fluxes of the Lena River Delta
}

\author{
Tina Sanders (1), Claudia Fiencke, Matthias Fuchs, Charlotte Haugk, \\ Bennet Juhls, Gesine Mollenhauer, Olga Ogneva, Paul Overduin, \\ Juri Palmtag, Vasily Povazhniy, Jens Strauss, Robyn Tuerena, \\ Nadine Zell, Kirstin Dähnke
}

Received: 5 May 2021/Revised: 7 September 2021 / Accepted: 1 November 2021 / Published online: 16 December 2021

\begin{abstract}
The Arctic is nutrient limited, particularly by nitrogen, and is impacted by anthropogenic global warming which occurs approximately twice as fast compared to the global average. Arctic warming intensifies thawing of permafrost-affected soils releasing their large organic nitrogen reservoir. This organic nitrogen reaches hydrological systems, is remineralized to reactive inorganic nitrogen, and is transported to the Arctic Ocean via large rivers. We estimate the load of nitrogen supplied from terrestrial sources into the Arctic Ocean by sampling in the Lena River and its Delta. We took water samples along one of the major deltaic channels in winter and summer in 2019 and sampling station in the central delta over a one-year cycle. Additionally, we investigate the potential release of reactive nitrogen, including nitrous oxide from soils in the Delta. We found that the Lena transported nitrogen as dissolved organic nitrogen to the coastal Arctic Ocean and that eroded soils are sources of reactive inorganic nitrogen such as ammonium and nitrate. The Lena and the Deltaic region apparently are considerable sources of nitrogen to nearshore coastal zone. The potential higher availability of inorganic nitrogen might be a source to enhance nitrous oxide emissions from terrestrial and aquatic sources to the atmosphere.
\end{abstract}

Keywords Arctic Ocean - Lena Delta $\cdot$ Nitrogen · Nitrous oxide

Supplementary Information The online version contains supplementary material available at https://doi.org/10.1007/s13280021-01665-0.

\section{INTRODUCTION}

The Arctic is warming at twice the rate of the global average (Smith et al. 2019). In the Arctic Ocean, for instance, sea ice, especially multi-year ice, is being lost at an unprecedented rate (Overland and Wang 2013). Longer ice-free periods result in potentially higher productivity and changes of food webs (Lewis et al. 2020). At the same time, increasing air temperatures are thawing permafrost around the Arctic Ocean (Biskaborn et al. 2019), which then release organic matter including nitrogen to river and further on to the Arctic Ocean.

The permafrost-affected soils store a globally large amount of organic matter, including organic carbon (OC) and nitrogen $(\mathrm{N})$. It is estimated that more than half of the global soil organic matter (SOM) are stored within the northern permafrost region. Hugelius et al. (2014) estimated a total SOC stocks in the northern circumpolar permafrost region of $\sim 1300 \mathrm{Pg} \pm 200 \mathrm{Pg}$. A recent publication by Mishra et al. (2021) based on $>2700$ soil profiles estimated a total SOC stock of 1000 ( -170 to + $186 \mathrm{Pg}$ ) to $300 \mathrm{~cm}$. Circumpolar estimate for $\mathrm{N}$ ranged between 40 and $67 \mathrm{Pg} \mathrm{N}$ (Weintraub and Schimel 2003; Harden et al. 2012). Compared to SOC stocks, we know little about the $\mathrm{N}$ stocks in the permafrost zone, which are therefore a subject of ongoing debate. For instance, based on typical soil C:N ratios of $10-50$ and scaled to the amount of SOC, the actual $\mathrm{N}$ stock in permafrost-affected soils could reach $130 \mathrm{Pg} \mathrm{N}$ (Voigt et al. 2020). Abbott and Jones (2015) suggest that globally relevant quantities of $\mathrm{N}$ are stored in permafrost soils.

These stocks are prone to be reactivated by thawing ground ice, which leads to a suite of mass wasting and subsidence processes such as thermokarst. The release of $\mathrm{N}$ stocks also results from fluvial (Kanevskiy et al. 2016; 
Fuchs et al. 2020) and coastal erosion (Günther et al. 2013). In order to understand $\mathrm{N}$ release and its utilization as a consequence of permafrost thaw, we need studies that combine investigations of soil $\mathrm{N}$ cycling with soil erosion, soil release of reactive nitrogen to the rivers, and transport to the Arctic Ocean. Reactive nitrogen are components (dissolved inorganic $\mathrm{N}$ (DIN) and dissolved organic $\mathrm{N}$ $(\mathrm{DON})$ ), which are available for primary producers such as plants and microorganisms.

There are some studies on $\mathrm{N}$ cycling in permafrost-affected soils (e.g., Biasi et al. 2005; Stewart et al. 2014; Sanders et al. 2019; Horn and Hetz 2021). Recent newer studies focus on the potential nitrous oxide $\left(\mathrm{N}_{2} \mathrm{O}\right)$ emissions from permafrost-affected soils (reviewed by Voigt et al. (2020)) and the input of $\mathrm{C}$ and $\mathrm{N}$ into the fluvial system (Hugelius et al. 2020; Pastor et al. 2020). While most $\mathrm{N}$ turnover occurs during summer, winter $\mathrm{N}$ mineralization may provide an important $\mathrm{N}$ source upon thaw in spring, when a pulse of nitrate $\left(\mathrm{NO}_{3}{ }^{-}\right)$in soil solution has been observed in studies of Arctic ecosystems (Schimel and Bennett 2004; Buckeridge et al. 2013; Rasmussen et al. 2020). Inorganic dissolved nitrogen or small dissolved organic $\mathrm{N}$ compounds such as urea or amino acids can contribute to primary productivity in soils (Schimel and Bennett 2004) and nevertheless, nitrogen and phosphorus are limiting nutrients in the Arctic ecosystems such as soils and rivers (Shaver et al. 1986; Beermann et al. 2014; Schade et al. 2016; Hobbie et al. 2021).

Other studies have investigated $\mathrm{N}$ fluxes in Arctic rivers (Dittmar and Kattner 2003; Frey and McClelland 2009; Holmes et al. 2012); rivers receive a large portion of $\mathrm{N}$ from soils during the spring freshet, which is consumed during summer (Buckeridge et al. 2010; Abbott and Jones 2015). N is mainly transported to the Arctic Ocean as DON and $\mathrm{NO}_{3}{ }^{-}$(Holmes et al. 2012). The mean riverine $\mathrm{NO}_{3}{ }^{-}$ contribution to ocean primary production in the Arctic is generally low and is approx. 5\% for the Laptev Sea (Le Fouest et al. 2015). Both nitrite $\left(\mathrm{NO}_{2}{ }^{-}\right)$and ammonium $\left(\mathrm{NH}_{4}{ }^{+}\right)$are rapidly converted into $\mathrm{NO}_{3}{ }^{-}$or assimilated by plants or phytoplankton. However, rapid uptake of DIN, coupled with relatively quick regeneration of dissolved organic nitrogen (DON) in N-limited nearshore regions, could potentially lead to high local rates of riverine-supported photosynthesis (Tank et al. 2012). Arctic rivers annually carry $\sim 13 \%$ of the freshwater transported globally from land to ocean, though the Arctic Ocean only makes up approximately $1 \%$ of the total global ocean volume. (Aagaard and Carmack 1989; Anderson et al. 1998). Throughout the Eurasian Shelf region, rapid summertime depletion of $\mathrm{NO}_{3}{ }^{-}$across the full fluvial-marine transition in the Laptev Sea indicates N limitation (Kattner et al. 1999; Dittmar and Kattner 2003; Reyes and Lougheed 2015).

Across the entire Arctic, the influx of DON to the Arctic shelf waters from rivers is five times greater compared to the influx of $\mathrm{NO}_{3}{ }^{-}$(Dittmar and Kattner 2003) and also $70 \%$ of the DON is removed in shelf waters before even reaching the open marine environment (Thibodeau et al. 2017). In the nearshore regions, the riverine nutrients (organic and inorganic) have the greatest influence on productivity (Dunton et al. 2006). However, Tank et al. (2012) found that riverine nutrients are not sufficient to explain a large proportion of primary production in the Arctic Ocean. Although, Terhaar et al (2021) reported recently that riverine inputs indeed fuels primary production, but that satellite-based primary production rates might be overestimated especially for the Laptev and East Siberian Seas. It is important, therefore, to understand how much permafrost degradation may impact $\mathrm{N}$ forms and amounts from delta to nearshore environments, and the potential changes to the riverine and coastal nitrogen cycle and the ratio between its organic and inorganic N components. Generally, estuarine and deltaic regions are filters for riverine inputs to the coastal waters and the open ocean (Smith et al. 2005). They can also be a considerable source of $\mathrm{N}_{2} \mathrm{O}$ emissions (Seitzinger and Kroeze 1998; Dunton et al. 2006; Marzadri et al. 2021), nevertheless, $\mathrm{N}_{2} \mathrm{O}$ emissions from Arctic rivers and deltas are as yet poorly investigated.

In this study, we want to assess the amount of nitrogen which is released and transported from terrestrial sources to the Lena River and further through its delta towards the nearshore Laptev Sea. Based on our findings, we discuss the implications that thawing permafrost and release of reactive nitrogen may have on the ecosystem and the nitrogen cycle. In addition, we explore whether the increasing availability of reactive inorganic nitrogen in soils and rivers can potentially cause increasing $\mathrm{N}_{2} \mathrm{O}$ emissions.

\section{MATERIALS AND METHODS}

In this study, we present nutrient data focusing on $\mathrm{N}$ from two cruises in winter and summer 2019 from the inner Lena Delta to the nearshore Laptev Sea and a one-year monitoring data set from the Research Station Samoylov in 2018 and 2019 (see (Juhls et al. 2020)). Furthermore, in order to estimate soil release of organic matter including $\mathrm{C}$ and $\mathrm{N}$, soil incubation experiments were conducted. We measured the release of inorganic $\mathrm{N}$ forms by remineralization and nitrification and potential nitrous oxide $\left(\mathrm{N}_{2} \mathrm{O}\right)$ production. 

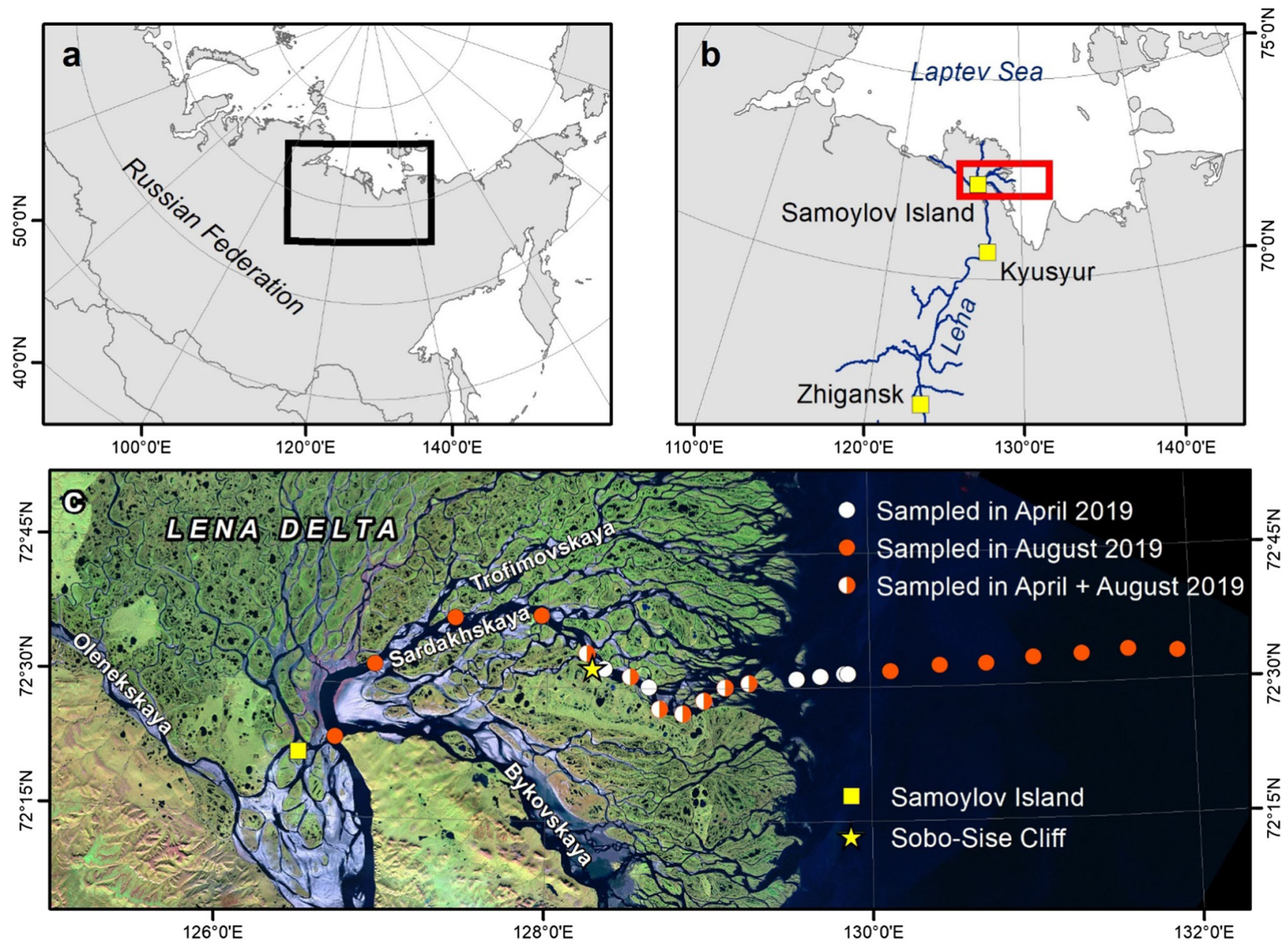

Fig. 1 Study site area of the Lena Delta in Northeast Siberia (a). Lena River and Delta including the ArcticGRO station in Zhigansk, the gauge station in Kyusyur, and the Samoylov Station (b). Transect and sampling sites of the cruises in winter (white dots) and summer (red dots), Samoylov Island, sampling site for soil incubations and the one-year data set, Sobe-Sibe Cliff (c)

\section{River study site and cruises}

The Lena Delta is located in northeastern Siberia, where the Lena River cuts through the Verkhoyansk Mountains range and discharges into the Laptev Sea, a shallow shelf sea in the Arctic Ocean. The Lena is divided in three major channels, the Olenekskaya flowing to the western Laptev Sea and the Trofimovskaya, which bifurcates into the Sardakhskaya and Bykovskaya channels, both flowing into the eastern Laptev Sea (Fig. 1) (Fedorova et al. 2015). Samples were collected along the Sardakhskaya Channel in late winter (March/April 2019) and summer (August 2019). The Sardakhskaya Channel has a water discharge of $8000 \mathrm{~m}^{3} \mathrm{~s}^{-1}$, which represent up to $40 \%$ of the discharge of the Lena main channel (Fedorova et al. 2015). The Lena River is ice-covered for about 8 months a year between October and May with an ice thickness of up to $2 \mathrm{~m}$. Water depth at the beginning of the Sardakhskaya Channel can reach $22 \mathrm{~m}$ (Fedorova et al. 2015) and is approximately
$11 \mathrm{~m}$ in front of Sobo-Sise cliff (Fuchs et al. 2020), so that water flows underneath the river ice cover during the winter months (Fuchs et al. (in review)).

Water, suspended particulate matter (SPM), and surface sediment samples were collected. Overall, 24 stations were sampled: at seven sites were sampled in both winter and summer, with an extra six sites sampled in winter only, and an extra 11 sites sampled in summer only (Fig. 1C).

In winter, water samples were collected from beneath the ice, if possible, additional on the halfway down and above the sediment through holes drilled through the river ice (ca. $2 \mathrm{~m}$ thickness) using an UWITEC water sampler. Holes were drilled at 5-km intervals until approximately $30 \mathrm{~km}$ offshore. Conductivity, temperature, and depth (CTD) were measured at each station using a SontekTM CastAway CTD sensor. Water samples were filtered directly in the field through pre-combusted GF/F glass fiber filters $(0.7 \mu \mathrm{m}$, Whatman) and stored frozen in HDPE bottles until thawed for further analysis. 
In summer, the transect was sampled in two short campaigns: (1) from offshore to the nearshore in the Laptev Sea with the marine vessel Anatoliy Zhilinskiy and (2) from the board of the river ship Merzlotoved along the Sardakhskaya channel. In the Laptev Sea, we sampled the water column at three different depths, $1 \mathrm{~m}$ below the water surface, halfway down the water column, and just above the riverbed or seabed. In the Lena Delta, one to three water samples were taken depending on the water depth. Additionally, sediment samples were taken using a gravity corer (from which the overlying bottom water was sampled).

121 river water samples were collected at the Samoylov research station from September 2018 to September 2019. The sampling procedure is described in detail in Juhls et al. (2020). Water samples were collected from just below the river surface in the center of the Olenekskaya Channel near Samoylov Island in a pre-rinsed HDPE bottle. Samples were collected from a boot during the ice-free period and from the ice during the winter. When ice break-up or freeze-up made access dangerous, samples were taken from the shore of Samoylov Island.

\section{Soil study site and incubations}

Soil was sampled from different soil types and geomorphologic units on Samoylov Island. The soils of Samoylov represent the main Holocene soil types in the younger part of the Lena Delta. The island can be divided into two major geomorphological units (Sanders et al. 2010), which vary in moisture regime and in SOM (Boike et al. 2013) (Fig. 2). The western part of Samoylov Island represents a relatively young floodplain up to $4 \mathrm{~m}$ above river level (a.r.l.), which is flooded in spring. The eastern part of Samoylov Island is an elevated (10-16 m a.r.l.) river terrace of late Holocene age. The river terrace is flooded only during extreme flooding events (Kutzbach et al. 2004). Soil types and characteristics are described in detail elsewhere (Sanders et al. 2010; Zubrzycki et al. 2013).

Soils were sampled from the floodplain and elevated river terrace. For the measurement of the OM content, extractable DIN, and the incubation setups, soil was sampled from polygonal tundra, cliff, and beach at seven sites (Fig. 2). Permafrost was sampled from the cliff face of Samoylov Island on the river terrace (K1 and K3). The cliff was exposed by ongoing thawing and erosion. At K1, soil was sampled from a former polygon center in a depth of
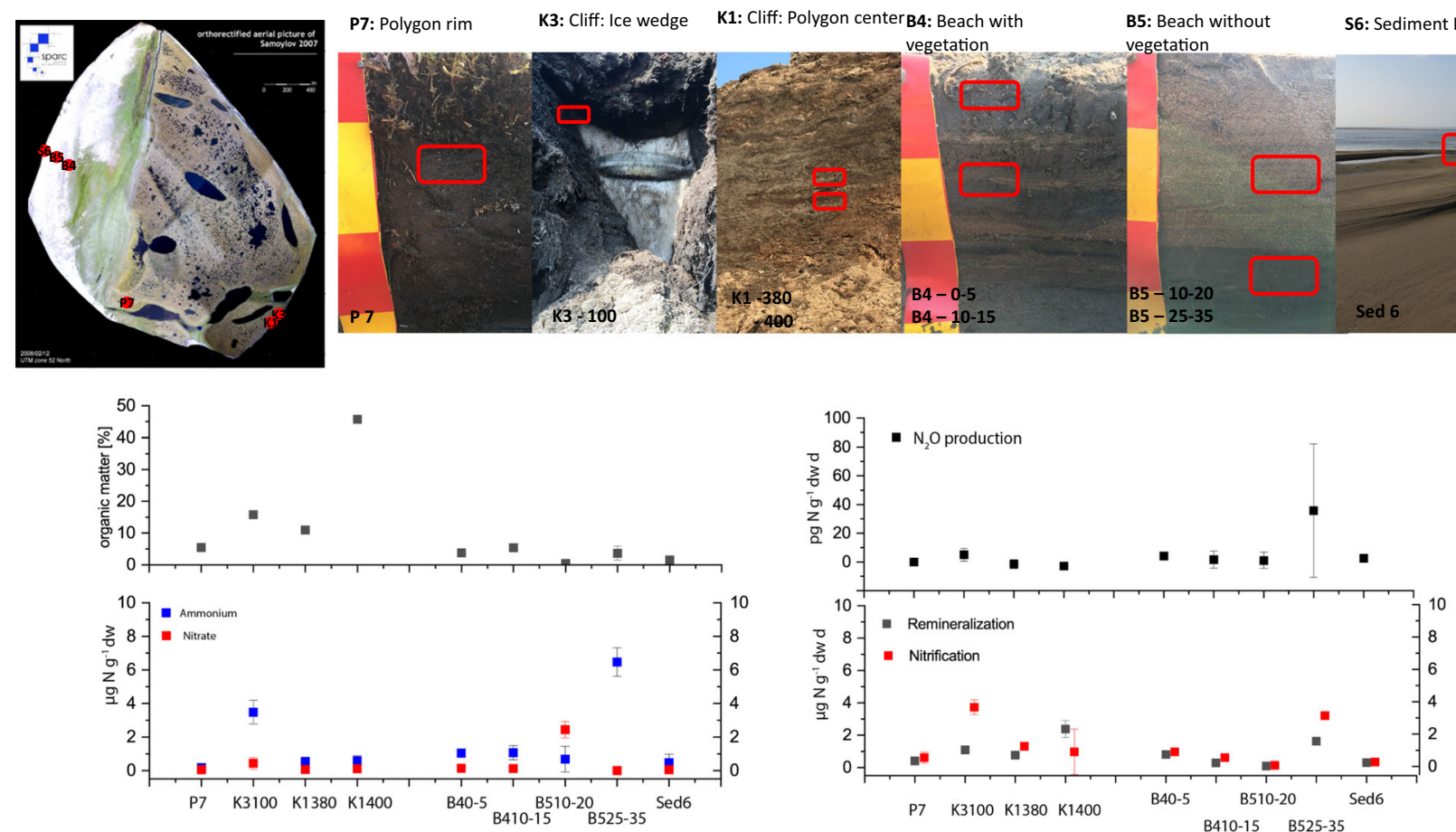

Fig. 2 Properties of investigated soils and their remineralization, nitrification and $\mathrm{N}_{2} \mathrm{O}$ production rates. Soil samples were taken at 6 different sites: K1 (cliff, former polygon center) in two depth 3.8 and $4.0 \mathrm{~m}$ below the ground surface, $\mathrm{K} 2$ (cliff, former polygon wall, close to the ice wedge), $1.0 \mathrm{~m}$ below the ground surface, P7 (polygon wall), depth 10-20 cm, B4 (beach, primary vegetation cover), 0-5 cm and 10-20 cm, B5 (beach without vegetation cover), $10-20 \mathrm{~cm}$ and $25-35 \mathrm{~cm}$, Sed6 (sediment in the Lena) as surface sediment. Organic matters were measured by combustion at $550{ }^{\circ} \mathrm{C} ; \mathrm{NO}_{3}{ }^{-}$and $\mathrm{NH}_{4}{ }^{+}$were extracted by $0,0125 \mathrm{M} \mathrm{KCl}$; remineralization and nitrification rates were measured by incubation of soil in Lena water; $\mathrm{N}_{2} \mathrm{O}$ production rates were measured after soil samples were transported to Germany 
3.8 and $4 \mathrm{~m}$ below the ground surface. In addition, the polygonal tundra (P7) were sampled at a polygon rim in $10-20 \mathrm{~cm}$. At K3 soils were sampled next to an ice wedge and originated from a former polygon rim in $1 \mathrm{~m}$ below the ground surface. Furthermore, a transect was sampled from the floodplain to the beach into the Lena River sediment at different depths (B4: 0-5 cm and 10-15 cm, B5: $10-20 \mathrm{~cm}$ and $25-35 \mathrm{~cm}$, and S6: surface sediment). Primary vegetation was present only at sampling site B4. The other sites were bare soil (Fig. 2).

Soil samples were incubated in Lena water to quantify the remineralization and nitrification of organic $\mathrm{N}$ to inorganic $\mathrm{N}\left(\mathrm{NH}_{4}{ }^{+}\right.$and $\left.\mathrm{NO}_{3}{ }^{-}\right)$. We followed two different approaches for sample analysis: (1) Analyses during the field campaign in 2019 in the laboratory of the Samoylov Island Research Station to measure the net N-remineralization and net nitrification rates; (2) Analyses of frozen soil samples and Lena River water at the University of Hamburg to measure potential $\mathrm{N}_{2} \mathrm{O}$ production.

For the first analysis, $15-20 \mathrm{~g}$ of wet soils and $130 \mathrm{ml}$ unfiltered Lena water were incubated on a shaker (14 days, $110 \mathrm{rpm})$ at room temperature $\left(20-25^{\circ} \mathrm{C}\right)$. Subsamples of mixed overlying water were taken every $2-3$ days. At the end of the incubation, the remaining soil/sediment and the overlying water were sampled. To calculate net $\mathrm{N}$ remineralization and net nitrification, DIN was measured over time, and sediment and soil $\mathrm{TN}$ were determined at the end of the incubations.

In another incubation, we measured potential aerobic nitrous oxide production rates. $1 \mathrm{~g}$ fresh weight of homogenized soil was weighed in $100 \mathrm{ml}$ serum bottles. $20 \mathrm{ml}$ Lena River water was added and the bottles were sealed air-tight with rubber septa. Soil samples were incubated in 18 replicates at $5{ }^{\circ} \mathrm{C}$, without shaking in the dark. $3 \times 1 \mathrm{ml}$ gas samples were taken after 1,2,8,11, and 18 weeks, and $\mathrm{N}_{2} \mathrm{O}$ concentration was determined by gas chromatography (GC, Agilent Technologies 7890 A, Santa Clara, CA, USA).

\section{Laboratory analyses}

For this study, water, suspended particulate matter (SPM), and sediment were sampled. Soil samples were taken for incubation experiments. Dissolved nutrients $\left(\mathrm{NH}_{4}{ }^{+}, \mathrm{NO}_{2}{ }^{-}\right.$, $\mathrm{NO}_{3}{ }^{-}$), phosphate and silicate, total dissolved organic nitrogen and phosphorus (TDN and TDP), and dissolved carbon (DOC) were measured in filtered water samples. Total nitrogen and phosphorus (TN and TP) were measured in unfiltered water samples. SPM was analyzed for C and N content and $\delta^{15} \mathrm{~N}$. Sediment samples were analyzed for grain size, $\mathrm{C}$ and $\mathrm{N}$ content and $\delta^{15} \mathrm{~N}$. Soil and sediment samples from Samoylov Island were analyzed for their $\mathrm{OM}, \mathrm{C}, \mathrm{N}, \delta^{15} \mathrm{~N}$ and extractable dissolved inorganic $\mathrm{N}$ contents. A detailed description of the analytical methods is provided in the Supplementary Information.

\section{Estimation of nitrogen loads from the Lena River to the nearshore Laptev Sea}

We used the Samoylov monitoring data of 121 samples from September 2018 to August 2019 to calculate the annual $\mathrm{N}_{-} \mathrm{NO}_{3}{ }^{-}$and $\mathrm{TN}$ flux to the Arctic Ocean. We linearly interpolated between sampling days to obtain daily concentrations. To calculate discharge, we corrected the Lena River discharge data from the Roshydromet gauge station at Kyusyur (Shiklomanov et al. 2021.) for the travel time to the sampling station Samoylov Island (Juhls et al. 2020) Fig. 6). Daily concentration was multiplied with corrected daily discharge values and summed to calculate annual fluxes.

\section{RESULTS}

\section{Hydrographic properties from land to ocean}

During the winter cruises, we investigated a transect just in the Sardakhskaya channel. Water depth varied between 2 and $18 \mathrm{~m}$. Water temperature and salinity profiles showed little variation, with range from 0.05 to $0.18^{\circ} \mathrm{C}$ and 0.19 to 0.21 PSU (excluding site CAC19-F) (Fig. $3 \mathrm{a}+$ b). Measurements from site CAC19-F were anomalously warm $\left(2.17^{\circ} \mathrm{C}\right)$ with higher salinity values $(0.25 \mathrm{PSU})$ relative to all other samples.

During the summer cruises, we investigated a longer transect from the center of the delta to approx. $80 \mathrm{~km}$ outside the delta in the nearshore Laptev Sea. The water depth ranged from $20 \mathrm{~m}$ in the main channel, to less than $0.5 \mathrm{~m}$ at the edge of the delta. In the coastal Laptev Sea, water depths gradually increased to $22 \mathrm{~m}$. The temperature and salinity were homogenous in the water column within the delta compared to a strongly stratified water column in the coastal Laptev Sea. Salinity ranged from 0.1 in the delta to 30 in the deeper Arctic shelf water. Temperature ranged from $16{ }^{\circ} \mathrm{C}$ in the delta to $-1.0^{\circ} \mathrm{C}$ in the bottom water. (Fig. $4 \mathrm{a}+$ b).

The data of the winter and summer cruises are accessible in the Pangaea data base (https://doi.pangaea.de/10. 1594/PANGAEA.933187) (Fuchs et al. (in review)).

\section{Sediment properties from land to ocean}

The riverbed of the main channels near Samoylov and in the Sardakhskaya Channel consists of mostly sandy sediments with a sand content of over $98 \%$. The sediments in the nearshore Laptev Sea are muddier with a sand content 

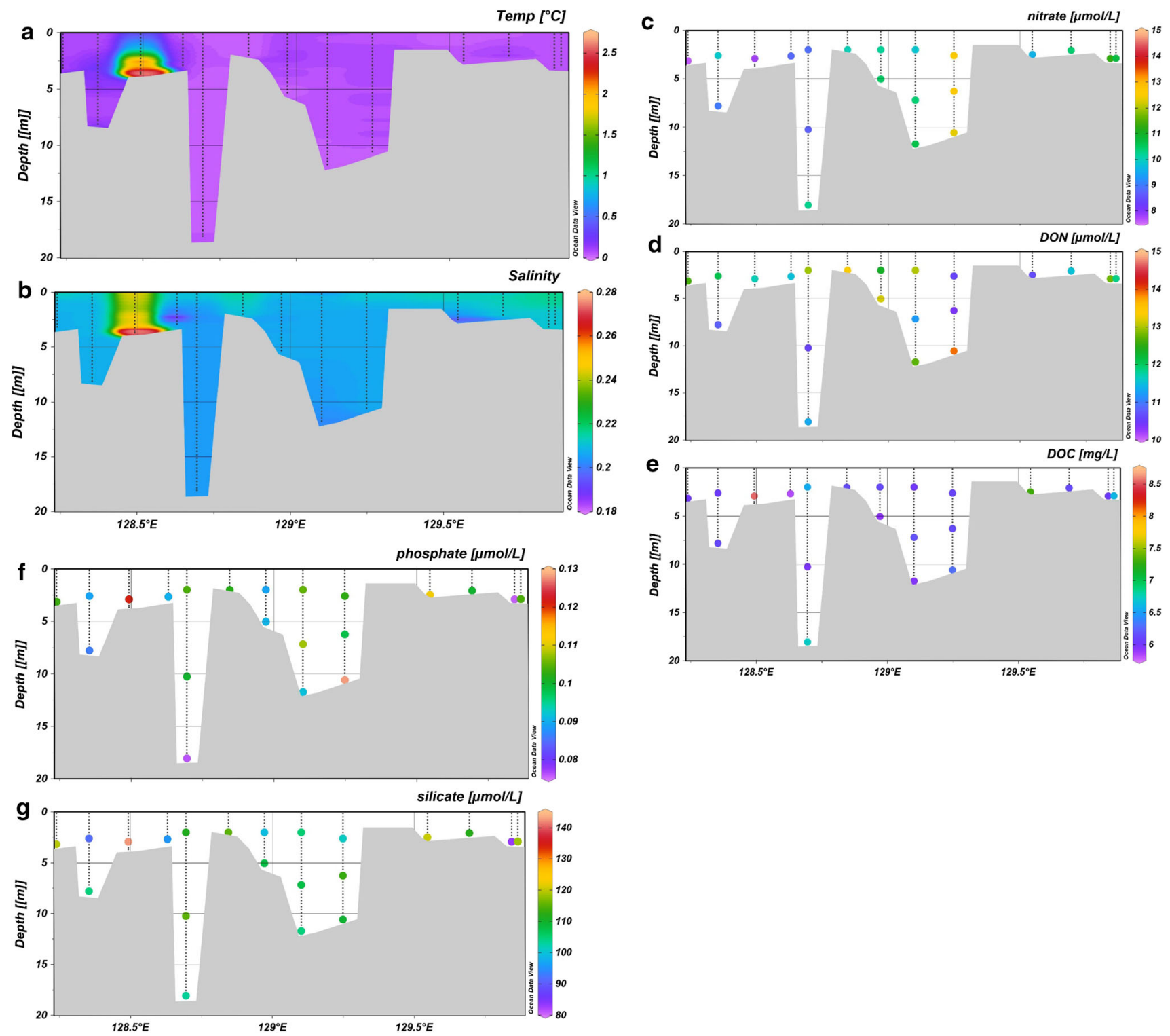

Fig. 3 Water properties and nutrient concentrations from the winter cruise. (a) temperature $\left({ }^{\circ} \mathrm{C}\right)$, $(\mathbf{b})$ salinity $(\mathrm{PSU}),(\mathbf{c})$ nitrate $(\mu \mathrm{mol} / \mathrm{L})$, (d) dissolved organic nitrogen (DON) $(\mu \mathrm{mol} / \mathrm{L})$, (e) dissolved organic carbon (DOC) $(\mathrm{mg} /)$, (f) phosphate $(\mu \mathrm{mol} / \mathrm{L})$, and $(\mathbf{g})$ silicate $(\mu \mathrm{mol} / \mathrm{L})$

below $10 \%$ and a silt content of over $50 \%$. The organic matter content of sediments in the delta is very low $(<0.2 \%)$. In the Laptev Sea, OC was between 2 and $3 \%$ and $\delta^{15} \mathrm{~N}$ values were slightly enriched in relation to the soils within the delta and ranged from 3.0 to $3.7 \%$ (Table 1).

\section{Nutrients from land to ocean}

Nutrient concentrations differed considerably between the winter and summer sampling campaigns. In winter, $\mathrm{NO}_{3}{ }^{-}$ and DON were present along the transect. In summer, $\mathrm{NO}_{3}{ }^{-}$was near the detection limit, DON and particulate $\mathrm{N}$ are dominant forms of $\mathrm{N}$ in the study region.

In winter, $\mathrm{NO}_{3}{ }^{-}$concentrations increased from the delta interior to the nearshore by $\sim 3 \mu \mathrm{mol} \mathrm{L}^{-1}$ from 7.5 to $10.5 \mu \mathrm{mol} \mathrm{L}{ }^{-1}$. DON remained relatively constant through

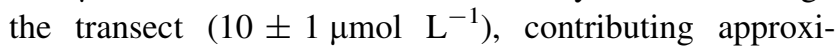
mately $50 \%$ of the dissolved $\mathrm{N}$ pool. $\mathrm{NH}_{4}{ }^{+}$concentrations were below $1.5 \mu \mathrm{mol} \mathrm{\textrm {L } ^ { - 1 }}$ in all samples apart from CAC19-F $\left(14.6 \mu \mathrm{mol} \mathrm{L}{ }^{-1}\right)$, suggesting that this sample may have been influenced by riverbed sediments. 

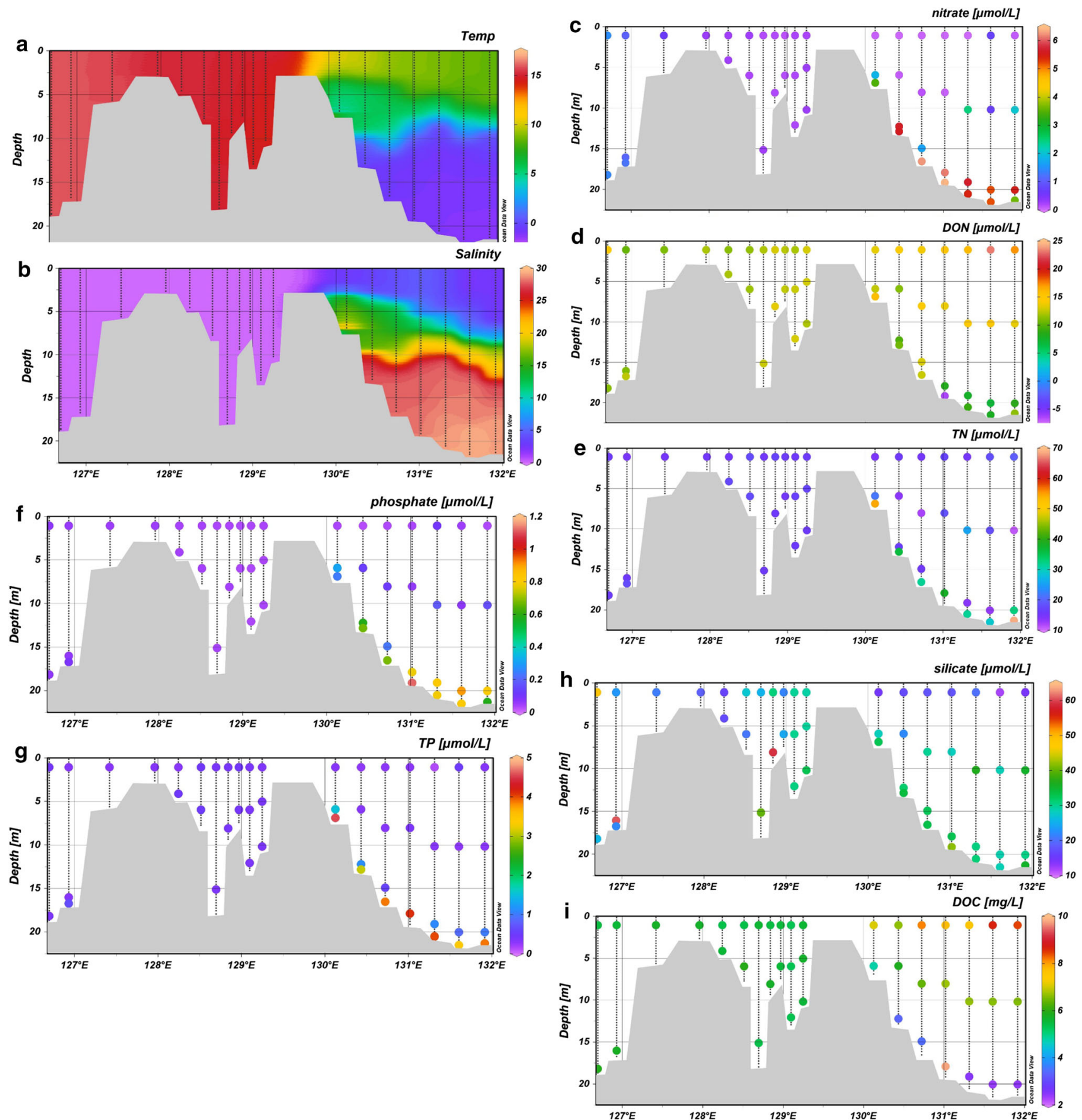

Fig. 4 Water properties and nutrient concentrations from the summer cruise. (a) Temperature $\left({ }^{\circ} \mathrm{C}\right),(\mathbf{b})$ salinity $(\mathrm{PSU}),(\mathbf{c})$ nitrate $(\mu \mathrm{mol} / \mathrm{L})$, (d) dissolved organic nitrogen $(\mathrm{DON})(\mu \mathrm{mol} / \mathrm{L}),(\mathbf{e})$ total nitrogen $(\mathrm{TN})(\mu \mathrm{mol} / \mathrm{L}),(\mathbf{f})$ phosphate $(\mu \mathrm{mol} / \mathrm{L}),(\mathbf{g})$ total phosphate $(\mathrm{TP})(\mu \mathrm{mol} / \mathrm{L})$, (h) silicate $(\mu \mathrm{mol} / \mathrm{L})$, and (i) dissolved organic carbon (DOC) $(\mathrm{mg} /)$

DOC concentrations were generally constant along the river-to-sea transect for all winter samples (except CAC19F), with a mean value of $6.2 \mathrm{mg} \mathrm{L}^{-1}$ and a minimum of $5.8 \mathrm{mg} \mathrm{L}^{-1}$ (Fig. 3).

In summer, the $\mathrm{NO}_{3}{ }^{-}$concentration was considerably lower than in winter. There was a decrease in $\mathrm{NO}_{3}{ }^{-}$(1.4 to
$0.2 \mu \mathrm{mol} \mathrm{L}^{-1}$ ) from the delta interior and in the beginning of the Sardakhskaya channel and a slight increase in DON (10 to $13 \mu \mathrm{mol} \mathrm{L} \mathrm{L}^{-1}$ ). The bottom water in the Laptev Sea had a $\mathrm{NO}_{3}{ }^{-}$concentration of approx. $5 \mu \mathrm{mol} \mathrm{L}{ }^{-1}$ (Fig. 4). 
Table 1 Sediment properties during the summer cruises in August 2019

\begin{tabular}{|c|c|c|c|c|c|c|c|c|c|c|c|}
\hline Sample ID & Longitude & Latitude & $\begin{array}{l}\text { Sand } \\
(\%)\end{array}$ & $\begin{array}{l}\text { Silt } \\
(\%)\end{array}$ & $\begin{array}{l}\text { Clay } \\
(\%)\end{array}$ & $\begin{array}{l}\text { Total } \\
\text { nitrogen }(\%)\end{array}$ & $\begin{array}{l}\text { Total nitrogen } \\
(\mu \mathrm{g} / \mathrm{g})\end{array}$ & $\begin{array}{l}\text { Total carbon } \\
(\%)\end{array}$ & $\begin{array}{l}\text { Total carbon } \\
(\mu \mathrm{g} / \mathrm{g})\end{array}$ & $\begin{array}{l}\delta^{15} \mathrm{~N} \\
(\%)\end{array}$ & $\mathrm{C} / \mathrm{N}$ \\
\hline \multicolumn{12}{|l|}{ Lena delta } \\
\hline CAC19-Lena 1 & 126.69564 & 72.39938 & 99.7 & 0.2 & 0.1 & 0.01 & 0.06 & 0.1 & 1.1 & n.d & 18.7 \\
\hline CAC19-Lena 2 & 126.92899 & 72.53734 & 99.6 & 0.3 & 0.1 & 0.01 & 0.08 & 0.2 & 2.2 & n.d & 27.1 \\
\hline CAC19-Lena 3 & 127.41932 & 72.62705 & 99.6 & 0.3 & 0.1 & 0.01 & 0.06 & 0.1 & 0.8 & n.d & 13.8 \\
\hline CAC19-Lena 4 & 127.95918 & 72.63351 & 99.5 & 0.4 & 0.0 & 0.01 & 0.06 & 0.1 & 1.1 & n.d & 18.5 \\
\hline CAC19-Lena 5 & 128.24466 & 72.56380 & n.d & n.d & n.d & n.d & n.d & n.d & n.d & n.d & n.d \\
\hline CAC19-Lena 6 & 128.51548 & 72.52111 & n.d & n.d & n.d & n.d & n.d & n.d & n.d & n.d & n.d \\
\hline CAC19-Lena 7 & 128.69504 & 72.46133 & 97.8 & 1.0 & 1.2 & 0.01 & 0.07 & 0.1 & 0.8 & n.d & 11.3 \\
\hline CAC19-Lena 7/8 & 128.84105 & 72.45303 & 99.0 & 0.4 & 0.6 & 0.00 & 0.04 & 0.1 & 1.1 & n.d & 27.3 \\
\hline CAC19-Lena 8 & 128.97076 & 72.47704 & 98.4 & 0.8 & 0.8 & 0.01 & 0.07 & 0.1 & 1.1 & n.d & 16.1 \\
\hline CAC19-Lena 8/9 & 129.09922 & 72.50168 & n.d & n.d & n.d & n.d & n.d & n.d & n.d & n.d & n.d \\
\hline CAC19-Lena 9 & 129.24841 & 72.50904 & 98.3 & 0.8 & 0.9 & 0.01 & 0.06 & 0.1 & 0.6 & n.d & 10.0 \\
\hline \multicolumn{12}{|l|}{ Laptev sea } \\
\hline CAC19-S-04 & 130.12630 & 72.53012 & 1.7 & 83.2 & 15.0 & 0.1 & 1.4 & 2.3 & 22.5 & 3.0 & 15.7 \\
\hline CAC19-S-05 & 130.43350 & 72.53983 & 10.1 & 67.5 & 22.4 & 0.2 & 1.6 & 2.3 & 23.4 & 3.3 & 14.4 \\
\hline CAC19-S-06 & 130.72248 & 72.54118 & 2.9 & 68.7 & 28.4 & 0.2 & 1.6 & 2.3 & 22.9 & 3.1 & 14.6 \\
\hline CAC19-S-07 & 131.01836 & 72.55056 & 2.3 & 66.1 & 31.6 & 0.2 & 1.6 & 2.2 & 22.1 & 3.2 & 13.9 \\
\hline CAC19-S-08 & 131.31468 & 72.55446 & 5.1 & 55.4 & 39.5 & 0.2 & 2.0 & 2.7 & 26.5 & 3.6 & 13.1 \\
\hline CAC19-S-09 & 131.60606 & 72.55886 & 0.6 & 56.7 & 42.8 & 0.2 & 2.2 & 2.8 & 28.0 & 3.7 & 12.8 \\
\hline CAC19-S-10 & 131.91480 & 72.55320 & 2.7 & 58.6 & 38.7 & 0.2 & 1.8 & 2.2 & 22.0 & 3.6 & 12.0 \\
\hline
\end{tabular}

n.d. not determined. $C N$ ratio of $\mathrm{TN}$ and $\mathrm{TC}$

\section{Nutrients at the Samoylov monitoring station}

At the Samoylov monitoring station, nutrient concentrations were measured from September 2018 to September 2019, including nitrate + nitrite (herein presented as $\left.\mathrm{NO}_{3}{ }^{-}\right), \mathrm{NH}_{4}{ }^{+}$, phosphate $\left(\mathrm{PO}_{4}{ }^{3-}\right)$, silicate, and $\mathrm{TN}$ (Figs. 5, 6). $\mathrm{NO}_{3}{ }^{-}$was detectable during periods of ice cover from October to June, reached highest concentration during the spring flood and then dropped below the detection limit. The $\mathrm{NH}_{4}{ }^{+}$concentrations ranged from below detection limit up to $12 \mu \mathrm{mol} \mathrm{L} \mathrm{L}^{-1}$. There was a clear increase in $\mathrm{NH}_{4}^{+}$when the Lena ice cover built up from October to December. The phosphate ${ }^{-}$concentrations ranged from below the detection limit up to $0.4 \mu \mathrm{mol} \mathrm{L}{ }^{-1}$, during the spring flood the concentration increased to more than $1.0 \mu \mathrm{mol} \mathrm{L}{ }^{-1}$. The silicate concentration showed a clear seasonal cycle with an increase during the ice-covered months from approx. $50 \mu \mathrm{mol} \mathrm{L}{ }^{-1}$ to slightly above $100 \mu \mathrm{mol} \mathrm{L}{ }^{-1}$. The TN (DIN + DON + particulate $\left.\mathrm{N}\right)$ values (Fig. 6) showed a similar pattern with higher but more variable concentrations in winter and lower concentration in summer. From September 2018 to August 2019, we estimated an annual $\mathrm{N}-\mathrm{NO}_{3}{ }^{-}$load of $24.5 \mathrm{Gg}$ year ${ }^{-1}$ and a total $\mathrm{N}$ load of $242.1 \mathrm{Gg}_{\mathrm{year}}{ }^{-1}$.

\section{Nutrient and potential $\mathrm{N}_{2} \mathrm{O}$ release and transport from soils to river}

We incubated two types of soil samples: firstly, organicrich and peaty soils of the polygonal tundra which can enter the Lena River after thawing and erosion at the cliffs of the Samoylov Island, and secondly, soils and sediment from the floodplain, which are regularly flooded by the Lena River and contain mostly allochthonous organic matter from the river.

The soil samples differed mainly in SOM, which ranged from 0.5 to $45.7 \%$. SOM of the polygonal tundra and the cliff was generally higher (above 5\%) than in soils from the floodplain (0.5-5.8\%) (Table 2).

The $\mathrm{NH}_{4}{ }^{+}$content of the soils ranged between 0.1 and $6.5 \mu \mathrm{g} \mathrm{N} \mathrm{g}^{-1} \mathrm{dw}$. The highest concentration was found in the peat containing cliff and the organic-rich layer of the beach. A considerable amount of $\mathrm{NO}_{3}{ }^{-}$was detected in the sandier layer of the beach.

The soil and sediment samples from the floodplain were sandy to silty with a sand content between 50 and $98 \%$. Silt content increased with distance from the water line of the river. The soils from the river terrace contained less sand, whereas SOM was higher than in the floodplain samples. The $\delta^{15} \mathrm{~N}$ values of river terrace soils were lower than those 

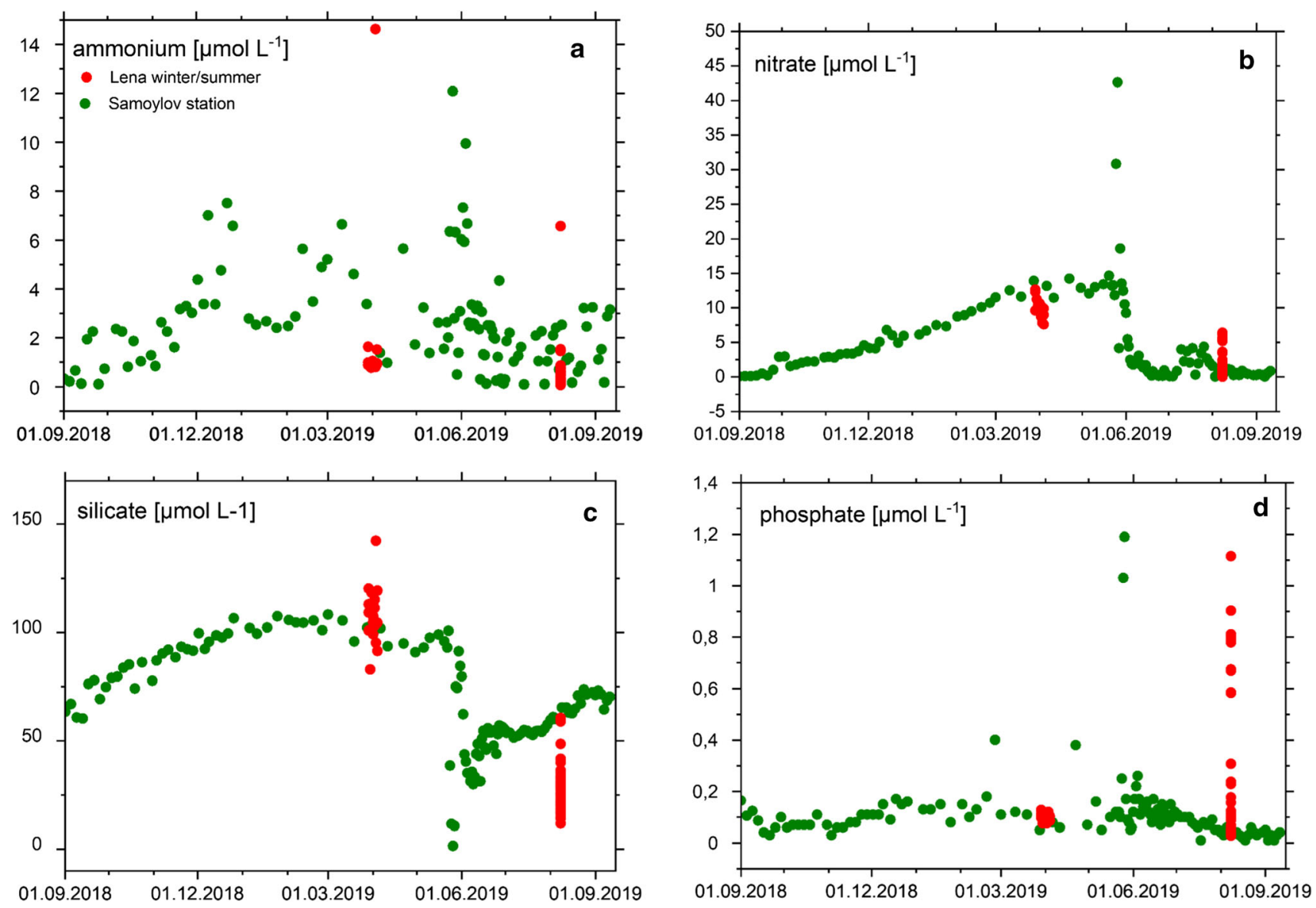

Fig. 5 Nutrient data from Samoylov Monitoring station September 2018-September 2019 (green) and data from the two Lena cruises in winter and summer 2019 in this study (red). a Ammonium ( $\mu \mathrm{mol} / \mathrm{L}), \mathbf{b}$ nitrate $(\mu \mathrm{mol} / \mathrm{L})$, c silicate $(\mu \mathrm{mol} / \mathrm{L})$, and d phosphate $(\mu \mathrm{mol} / \mathrm{L})$

found in the floodplain (Table 2) and ranged between 0.6 and $1.6 \%$, which is close to the average of the atmospheric $\mathrm{N}_{2}$ of $0 \%$ (Kendall 1998).

In all soil incubations, DIN production occurred. The samples with high $\mathrm{NH}_{4}{ }^{+}$concentrations such as $\mathrm{K} 3$ near the ice wedge and the deeper sample from the beach (B5 25-35) also had higher $\mathrm{NH}_{4}{ }^{+}$concentrations during the incubation and showed an increase of $\mathrm{NO}_{3}{ }^{-}$after a maximum of five days. The net $\mathrm{N}$-remineralization rates ranged between 0.1 and $1.7 \mu \mathrm{g} \mathrm{N} \mathrm{g}{ }^{-1} \mathrm{~d}^{-1}$ and they correlated with the organic matter content $\left(R^{2}\right.$ of 0.72$)$ and OC $\left(R^{2}\right.$ of 0.65$)$ (Fig. 2).

The net nitrification rates ranged between 0.1 and $5.0 \mu \mathrm{g} \mathrm{N} \mathrm{g}^{-1}$ day $^{-1}$ (Fig. 2). The highest rates were observed in the organic- and ammonium-rich cliff and beach soils. The nitrification rates correlated $\left(R^{2}\right.$ of 0.92$)$ with the $\mathrm{NH}_{4}^{+}$concentration.

We also investigated the potential $\mathrm{N}_{2} \mathrm{O}$ production of soils from the delta region. A considerable $\mathrm{N}_{2} \mathrm{O}$ production was only detected in the incubations after 8 weeks at $5{ }^{\circ} \mathrm{C}$ in the non-vegetated subsoil samples of the floodplain, containing higher SOM than the topsoil, with mean $\mathrm{N}_{2} \mathrm{O}$ production rate of $35.7 \pm 46.5 \mathrm{pg} \mathrm{N}^{-\mathrm{N}_{2} \mathrm{O} \mathrm{g} \mathrm{dw}}{ }^{-1}$ day $^{-1}$ (Fig. 2). In all the other incubations, the $\mathrm{N}_{2} \mathrm{O}$ formation was near the detection limit.

\section{DISCUSSION}

\section{Nitrogen signal in the Lena Delta}

Dissolved $\mathrm{N}$ was exported mostly as $\mathrm{DON}$ and $\mathrm{NO}_{3}{ }^{-}$ during the winter, whereas DON prevailed in the delta in summer. These results corroborate observations from the Arctic GRO data from Zhigansk in the south (Holmes et al. 2012, 2021).

In winter (October to May), $\mathrm{DON}, \mathrm{NH}_{4}^{+}$, and $\mathrm{NO}_{3}{ }^{-}$ were continuously released to the aquatic environment, resulting in relatively high and uniform concentrations of $\mathrm{NO}_{3}{ }^{-}$and DON in the water column (Fig. 3C, D and 5). After the growing season, when the active layer freezes, we observed a clear increase of $\mathrm{NO}_{3}{ }^{-}$and $\mathrm{NH}_{4}^{+}$at the 


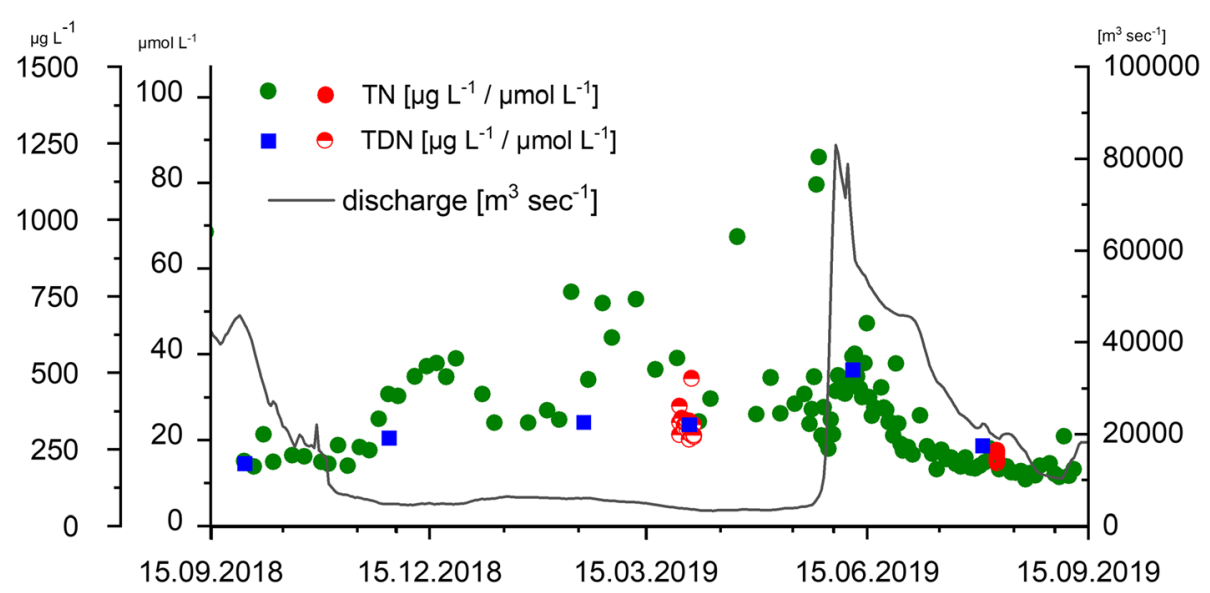

Fig. 6 Total $\mathrm{N}\left(\mu \mathrm{g} \mathrm{L}^{-1}\right.$ and $\left.\mu \mathrm{mol} \mathrm{L}{ }^{-1}\right)$ concentration at the Samoylov Monitoring (green) from 15.9.2018 to 15.9.2019 and from the summer cruises (red, sites inside the delta). TDN $\left(\mu \mathrm{g} \mathrm{L}^{-1}\right.$ and $\mu \mathrm{mol} \mathrm{L}^{-1}$ ) concentration from the winter cruises (half-red circles) and from the ArcticGRO station (blue square, Holmes et al. 2021) from 15.9.2018 to 15.9.2019. Discharge (black line) in $\mathrm{m}^{3} \mathrm{sec}^{-1}$ at the gauge station Kyusyur

Table 2 Soil properties of samples from Samoylov Island

\begin{tabular}{|c|c|c|c|c|c|c|c|c|c|c|c|c|}
\hline Sample ID & $\begin{array}{l}\text { Depth } \\
(\mathrm{cm})\end{array}$ & $\begin{array}{l}\text { Sample } \\
\text { site }\end{array}$ & $\begin{array}{l}\text { Sand } \\
(\%)\end{array}$ & $\begin{array}{l}\text { Silt } \\
(\%)\end{array}$ & $\begin{array}{l}\text { Clay } \\
(\%)\end{array}$ & $\begin{array}{l}\text { SOM } \\
(\%)\end{array}$ & $\begin{array}{l}\text { Total } \\
\text { Nitrogen (\%) }\end{array}$ & $\begin{array}{l}\text { Total Nitrogen } \\
(\mu \mathrm{g} / \mathrm{g})\end{array}$ & $\begin{array}{l}\text { Total } \\
\text { Carbon (\%) }\end{array}$ & $\begin{array}{l}\text { Total Carbon } \\
(\mu \mathrm{g} / \mathrm{g})\end{array}$ & $\begin{array}{l}\delta^{15} \mathrm{~N} \\
(\% 0)\end{array}$ & $\mathrm{C} / \mathrm{N}$ \\
\hline \multicolumn{13}{|l|}{ Polygonal tundra } \\
\hline LD19P7 & $10-20$ & P7 & 55.9 & 37.2 & 6.9 & 6.0 & 0.1 & 1.4 & 2.5 & 25.4 & 0.7 & 18.4 \\
\hline LD19K3 & 100 & $\mathrm{~K} 3$ & 31.9 & 56.2 & 11.9 & 15.8 & 0.4 & 3.9 & 8.9 & 88.8 & 0.6 & 22.8 \\
\hline LD19K1 & 380 & $\mathrm{~K} 1$ & 15.7 & 69.9 & 14.4 & 10.9 & 0.3 & 2.7 & 5.5 & 54.9 & 1.0 & 20.3 \\
\hline LD19K2 & 400 & K1 & n.d & n.d & n.d & 45.7 & 0.4 & 3.9 & 16.2 & 162.1 & 0.8 & 41.3 \\
\hline \multicolumn{13}{|l|}{ Floodplain } \\
\hline LD19B4 0-5 & $0-5$ & B4 $0-5$ & 49.9 & 43.1 & 7.1 & 3.5 & 0.1 & 0.9 & 1.4 & 13.7 & 1.6 & 15.7 \\
\hline LD19B4 10-15 & $10-15$ & $\begin{array}{l}\text { B4 } \\
\quad 10-15\end{array}$ & 51.5 & 40.6 & 7.9 & 5.8 & 0.1 & 1.0 & 1.6 & 16.2 & 1.4 & 15.9 \\
\hline LD19B5 10-20 & $10-20$ & $\begin{array}{l}\text { B5 } \\
10-20\end{array}$ & 97.6 & 1.7 & 0.7 & 0.5 & 0.0 & 0.1 & 0.1 & 1.10 & n.d & 7.3 \\
\hline LD19B5 & $25-35$ & $\begin{array}{l}\text { B5 } \\
\quad 25-35\end{array}$ & 74.2 & 21.0 & 4.7 & 5.2 & 0.1 & 1.0 & 2.0 & 19.6 & 0.9 & 19.2 \\
\hline LD19Sed6 & $0-5$ & Sed 6 & 91.6 & 7.4 & 1.0 & 2.0 & 0.0 & 0.2 & 0.4 & 3.8 & n.d & 16.3 \\
\hline
\end{tabular}

n.d. not determined. $C N$ ratio of $\mathrm{TN}$ and $\mathrm{TC}$

Samoylov station. This allochthonous, terrestrial DIN was not consumed by plants, but rather leached to the river.

With warming and active layer deepening into mineral horizons with low $\mathrm{C} / \mathrm{N}$ ratios, the hydrological flow path penetrates deeper, intensifying $\mathrm{NO}_{3}{ }^{-}$and $\mathrm{NH}_{4}{ }^{+}$leaching to the river (Harms and Jones 2012). In soils with vegetation cover, plants and microbial communities will compete for remineralized DON and DIN (Stark and Kytöviita 2006). By the end of the growing season or in unvegetated soils, mineralization and nitrification will be the dominant processes. Therefore, winter $\mathrm{N}$ export from soils to rivers in the unfrozen active layer will be in the form of $\mathrm{NH}_{4}{ }^{+}$, $\mathrm{NO}_{3}{ }^{-}$, and DON. Especially, because by the end of the vegetation period, $\mathrm{NO}_{3}$ was enriched in soils without vegetation cover (Sanders et al. 2010).

In summer, the main $\mathrm{N}$ export from soils takes place via DON and $\mathrm{NH}_{4}{ }^{+}$, which is consistent with former studies in permafrost-affected soils (Harms and Jones 2012). In the river, $\mathrm{NH}_{4}{ }^{+}$and $\mathrm{NO}_{3}{ }^{-}$are consumed immediately (Dittmar and Kattner 2003), again either by primary producers or oxidized to nitrate. This was confirmed by our own results that $\mathrm{NH}_{4}^{+}$was not detectable in the Lena transect (Table S1) and nitrate dropped down from $1.5 \mu \mathrm{mol} \mathrm{L}^{-1}$ to close to the detection limit during the first stations in the inner Delta (Fig. 4C). We speculate that phytoplankton, likely diatoms, are responsible for this uptake (Hawkings 
et al. 2017). This is backed up by the low silicate concentration in summer (Fig. 5), we found up to $60 \mu \mathrm{mol} \mathrm{L}{ }^{-1}$ in summer and more than $100 \mu \mathrm{mol} \mathrm{\textrm {L } ^ { - 1 }}$ in winter. The SPM values, with high $\mathrm{N}$ percentage and low $\mathrm{C} / \mathrm{N}$ ratios, further support this, as they indicate the production of fresh biomass (Supplementary Table S1).

We do not have direct evidence for DON uptake in summer, but according to Redfield ratios, silicate uptake must be backed up by approximately equimolar $\mathrm{N}$ uptake. $\mathrm{N}$ is limited in the delta, and must either stem from rapid recycling or from direct DON uptake as is known from permafrost-affected soils (Schimel and Bennett 2004) and also in aquatic environments (Wheeler et al. 1974).

Overall, we conclude that soils and pore water can be sources of $\mathrm{NO}_{3}{ }^{-}$to the Lena Delta in winter, even though in low concentration (Heikoop et al. 2015) and that nitrate can also stem from in-situ nitrification. In summer, DIN overall is less important in the Delta, because it is used immediately, and we hypothesize that active DON uptake supports primary production in the water column of the Lena.

\section{Implications of thaw for the ecosystem}

The flux of $\mathrm{C}$ and $\mathrm{N}$ from the Lena River has been estimated previously: Hugelius et al. (2020) estimated losses into aquatic systems (dissolved and particulate organic matter) to be $0.022 \pm 0.02 \mathrm{Pg} \mathrm{C} \cdot$ year $^{-1}$ and $0.7 \pm 0.5 \mathrm{Tg}$ $\mathrm{N} \cdot$ year $^{-1}$. Wild et al. (2019) estimated an OC flux of $0.9 \mathrm{Tg}$ $\mathrm{C}$ year $^{-1}$ coming from permafrost and peat deposits. Based on the TDN data from the ArticGRO Station, an annual flux of approx. $170 \mathrm{Gg}$ year $^{-1}$ were estimated by Holmes et al (2012) for the year 2008 to 2012. In our single-year study from September 2018 to September 2019, we estimate an annual TN flux of $242.1 \mathrm{Gg}_{\text {year }}{ }^{-1}$. This is higher than the average of the ArcticGRO data.

Comparisons between years and between different locations along the Lena River are challenging due to the two factors as follows: (1) The differences that can be accounted to strongly varying seasonal differences and (2) geographical differences, e.g., sources of different regions of the catchment.

Additionally some issues have to be considered and discussed, for instance, the particulate nitrogen is missing in the ArcticGRO data. Based on data from the cruises in this study, approximately one-fifth of the TN is particulate $\mathrm{N}$, (average TN $16.0 \mu \mathrm{mol} \mathrm{L}{ }^{-1}$, average TDN $12.9 \mu \mathrm{mol}$ $\mathrm{L}^{-1}$ ) so this can partly explain the higher annual fluxes, we found. However, if we added 20 percent of $\mathrm{N}$ to the ArcticGRO data, the results still fall below our estimate of annual $\mathrm{N}$ flux by about $15 \%$ (approx.. $36 \mathrm{Gg}$ ), even though the $\mathrm{N}_{-} \mathrm{NO}_{3}{ }^{-}$load is comparable $(24.2 \mathrm{Gg}$ in our study compared to $24.0 \mathrm{Gg}$, Holmes et al. 2012). It is possible that this deviation merely represents inter-annual variability because we compare one single annual cycle to a longterm data set. However, our Samoylov Island monitoring data were collected at higher temporal resolution and closer to the mouth of the Lena than the ArcticGRO data. In particular, the higher temporal resolution improved flux estimates by capturing the higher nutrient concentrations during peak discharge in spring and short hydrological events.

Additionally, 2019, our year of study, was a dry year and the summer discharge was low. There was no correlation of TN concentration with discharge (Fig. 6). Especially during the ice-covered period, higher concentrations of TN were measured during relatively low discharge. During winter, TN values varied strongly and ranged

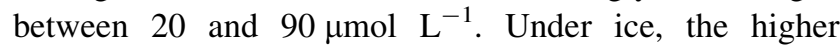
velocity and pressure can re-suspend materials from the sediment. The TN concentrations during the summer cruise in the delta were slightly higher than our annual station data, which could be an evidence that the delta itself adds a considerable $\mathrm{N}$ load to the Lena River (Fig. 6). Fuchs et al. (2020) calculated an annual eroded $\mathrm{N}$ amount to the Lena River from the Sobe-Sise Cliff (Fig. 1C) of $0.4 \times 10^{6} \mathrm{~kg}$ in the period of 2015-2018. The island is located downstream from Samoylov Island. Our soil incubations highlight that intense input can occur upon remineralization. Especially soils that were recently exposed by erosion are organic-rich and can release high amounts of DIN and DON.

This eroded soil material partly settled in the delta, in regions with low flow velocities, like on the beach of Samoylov Island. In the main channel, flow velocity is too high to allow for settling of organic-rich SPM. Instead, it is transported to the Laptev Sea, where it can be remineralized. However, only a minor part of the sediments transported by the Lena River enters the Laptev Sea shelf through the main channels of the delta, while the rest is dispersed within the network of the Lena Delta (Rachold et al. 1996).

Thibodeau et al. (2017) showed that the Lena River discharge mostly affects Laptev Sea surface water, while the bottom water is influenced by modified Atlanticderived water flowing along the continental slope and branching onto the shelf. Consequently, most ecosystem implications of nutrient supply from the Lena River affect the upper shelf waters. Secondary advective processes by currents can be responsible for along-shore drift of suspended OM once it discharges into the shelf area. Although our study and other previously published work identify high $\mathrm{N}: \mathrm{P}$ export from the Lena Delta, these high $\mathrm{N}: \mathrm{P}$ ratios are quickly lost and replaced with lower marine $\mathrm{N}: \mathrm{P}$ ratios (Tuerena et al. 2022). This suggests biological uptake and sedimentary denitrification that lead to a loss of $\mathrm{N}$ on the Laptev Sea shelf. 


\section{Potential $\mathrm{N}_{2} \mathrm{O}$ production in deposited and former eroded material}

To investigate the potential $\mathrm{N}_{2} \mathrm{O}$ production and further emission to the atmosphere, we incubated samples from different soil types in Lena water over 8 weeks. In most of our incubations, the $\mathrm{N}_{2} \mathrm{O}$ concentrations were close to the detection limit but one incubation was a significant exception. From the sample of an organic-rich buried layer on the beach of the floodplain of Samoylov Island, significant amounts of $\mathrm{N}_{2} \mathrm{O}$ were produced with approximately $36 \mathrm{pg} \mathrm{N}-\mathrm{N}_{2} \mathrm{O} \mathrm{g} \mathrm{dw}{ }^{-1} \mathrm{day}^{-1}$. Taking soil density into account, this corresponds to approximately $1000 \mu \mathrm{g}$ $\mathrm{N}_{2} \mathrm{O}-\mathrm{N} \mathrm{m}^{-2}$ day $^{-1}$. In this calculation, we ignored potential consumption of $\mathrm{N}_{2} \mathrm{O}$. Actual emissions require chamber measurements, and we acknowledge that this single measurements may estimate potential $\mathrm{N}_{2} \mathrm{O}$ emission. However, higher $\mathrm{N}_{2} \mathrm{O}$ production rates of 1080 to $10,030 \mu \mathrm{g} \mathrm{N} \mathrm{N}_{2} \mathrm{O}-\mathrm{N}$ $\mathrm{m}^{-2}$ day $^{-1}$ were determined in unvegetated permafrost peat soils (Marushchak et al. 2011). Voigt et al (2020) summarized that unvegetated soils generally show highest $\mathrm{N}_{2} \mathrm{O}$. Assuming that bare soils contribute to $\mathrm{N}_{2} \mathrm{O}$ emissions, the unvegetated floodplain in the delta, which contains layers of organic-rich deposits is a potential source of $\mathrm{N}_{2} \mathrm{O}$ emissions. Higher erosion rates, organic matter depositions within the delta, and higher $\mathrm{NH}_{4}{ }^{+}$and $\mathrm{NO}_{3}{ }^{-}$ load in the water column can trigger the $\mathrm{N}_{2} \mathrm{O}$ emissions in the future.

\section{CONCLUSIONS}

We found the Lena Delta region to play an important role as a source of reactive nitrogen stemming from the soil active layer and from thawing permafrost. Eroded soil materials release reactive, inorganic nitrogen and show significant rates or remineralization and nitrification. The inorganic nitrogen is almost completely utilized in the summer month and output to the coastal ocean is mainly organic nitrogen. Our estimate of nitrogen inputs in 2019 was $15 \%$ above the average data from the ArcticGRO stations further upstream in the Lena River. Though based on one annual cycle, this points towards additional $\mathrm{N}$-sources downstream of the ArcticGRO station. We attribute this difference to an underestimation of the particulate nitrogen flux from eroded soil material in summer and due to resuspension of sediments, particularly important in winter.

Despite these high $\mathrm{N}$ fluxes, the effect of $\mathrm{N}$ on primary production on the shelf to date appears limited. However, the erosion and especially input of organic-rich material, and its subsequent remineralization from organic matter over DON to DIN, potentially may increase the $\mathrm{N}_{2} \mathrm{O}$ production and emissions from permafrost-affected soils and in permafrost-influenced aquatic environments, though this must be affirmed by future measurements.

Potentially, the changes in release of organic and inorganic nitrogen from thawing permafrost might alleviate the nitrogen limitations, in soils, the river, and consequently also in the coastal water of the Arctic Ocean causing higher productivity at the primary producer level and across food webs.

\section{SOCIETAL AND POLICY IMPLICATIONS}

The Arctic is heavily impacted by climate change. Its air temperature increase is twice that of temperate regions (Smith et al. 2019). This increase in temperature is tied to extended thaw of permafrost-affected soils and increased soil organic matter decomposition. This increases the ubiquitous input of nutrients to the coastal ecosystem and enhances biogeochemical processes and availability of reactive nitrogen in the river and adjacent ocean. On a global scale, anthropogenic input of reactive nitrogen to the natural nitrogen cycle mainly by fertilization and industrial emission had imbalanced the cycle and these already exceed planetary boundaries (Steffen et al. 2011). That does not apply only to the over-fertilized temperate regions, but also to more pristine and oligotrophic ecosystems like the Arctic. Nonetheless, new data (Tuerena et al. 2022) suggest that the effect may be limited to the shelf region due to limited export to the open Arctic Ocean. Changing nutrient inputs potential increases coastal productivity, but temperature changes will also change the species composition in the coastal region. With possible increase in productivity, the ecosystem will be exposed to the increase in anthropogenic pressure, likely from fisheries.

The permafrost region is indicated as one tipping point regarding green-house gas emission of carbon dioxide and methane for the global climate system (Lenton et al. 2019). The main focus is usually put on methane and $\mathrm{CO}_{2}$ emissions, but it is yet unclear whether nitrous oxide production in Arctic soils and possibly in the rivers may intensify in the future and maybe contributed in particular to the tipping point. Global $\mathrm{N}_{2} \mathrm{O}$ emissions are increasing. Although atmospheric $\mathrm{N}_{2} \mathrm{O}$ is less concentrated than $\mathrm{CO}_{2}$ and $\mathrm{CH}_{4}$, it traps around 300 times more heat as a green-house gas. The $\mathrm{N}_{2} \mathrm{O}$ emissions from Arctic ecosystems could be one missing source in the global estimation.

The changing natural $\mathrm{N}$ cycle in the Arctic and the anthropogenic changed $\mathrm{N}$ cycle have to be considered together in the future. 
Acknowledgements This work is embedded into the Changing Arctic Ocean (CAO) program (lead by the NERC-BMBF Project EISPAC [\#03F0809A] and supported by the CACOON [\#03F0806A] and ARISE CAO projects. BJ was funded by the European Space Agency (ESA) as part of the Climate Change Initiative (CCI) fellowship (ESA ESRIN/Contract No. 4000133761/21/I-NB). We thank the Trofimuk Institute of Petroleum Geology and Geophysics, Siberian Branch of the Russian Academy of Sciences (IPGG SB RAS), Novosibirsk, Russia, for their efforts to run the Research Station Samoylov Island. We thank the captain and crew of the Anatoliy Zhilinskiy and the Merzlotoved for hosting us.

Funding Open Access funding enabled and organized by Projekt DEAL.

Open Access This article is licensed under a Creative Commons Attribution 4.0 International License, which permits use, sharing, adaptation, distribution and reproduction in any medium or format, as long as you give appropriate credit to the original author(s) and the source, provide a link to the Creative Commons licence, and indicate if changes were made. The images or other third party material in this article are included in the article's Creative Commons licence, unless indicated otherwise in a credit line to the material. If material is not included in the article's Creative Commons licence and your intended use is not permitted by statutory regulation or exceeds the permitted use, you will need to obtain permission directly from the copyright holder. To view a copy of this licence, visit http://creativecommons. org/licenses/by/4.0/

\section{REFERENCES}

Aagaard, K., and E.C. Carmack. 1989. The role of sea ice and other fresh water in the Arctic circulation. Journal of Geophysical Research: Oceans 94: 14485-14498.

Abbott, B.W., and J.B. Jones. 2015. Permafrost collapse alters soil carbon stocks, respiration, $\mathrm{CH} 4$, and $\mathrm{N} 2 \mathrm{O}$ in upland tundra. Global Change Biology 21: 4570-4587.

Anderson, L.G., K. Olsson, and M. Chierici. 1998. A carbon budget for the Arctic Ocean. Global Biogeochemical Cycles 12: $455-465$.

Beermann, F., A. Teltewskoi, C. Fiencke, E.-M. Pfeiffer, and L. Kutzbach. 2014. Stoichiometric analysis of nutrient availability $(\mathrm{N}, \mathrm{P}, \mathrm{K})$ within soils of polygonal tundra. Biogeochemistry. https://doi.org/10.1007/s10533-014-0037-4.

Biasi, C., W. Wanek, O. Rusalimova, C. Kaiser, H. Meyer, P. Barsukov, and A. Richter. 2005. Microtopography and plant-cover controls on nitrogen dynamics in hummock tundra ecosystems in Siberia. Arctic, Antarctic, and Alpine Research 37: 435-443.

Biskaborn, B.K., S.L. Smith, J. Noetzli, H. Matthes, G. Vieira, D.A. Streletskiy, P. Schoeneich, V.E. Romanovsky, et al. 2019. Permafrost is warming at a global scale. Nature Communications 10: $1-11$

Boike, J., B. Kattenstroth, K. Abramova, N. Bornemann, A. Chetverova, I. Fedorova, K. Fröb, M. Grigoriev, M. et al. 2013. Baseline characteristics of climate, permafrost and land cover from a new permafrost observatory in the Lena River Delta, Siberia (1998-2011). Biogeosciences 10: 2105-2128.

Buckeridge, K., E. Zufelt, H. Chu, and P. Grogan. 2010. Soil nitrogen cycling rates in low arctic shrub tundra are enhanced by litter feedbacks. Plant and Soil 330: 407-421.

Buckeridge, K.M., S. Banerjee, S.D. Siciliano, and P. Grogan. 2013. The seasonal pattern of soil microbial community structure in mesic low arctic tundra. Soil Biology and Biochemistry 65: 338-347.

Dittmar, T., and G. Kattner. 2003. The biogeochemistry of the river and shelf ecosystem of the Arctic Ocean: A review. Marine Chemistry 83: 103-120.

Dunton, K.H., T. Weingartner, and E.C. Carmack. 2006. The nearshore western Beaufort Sea ecosystem: Circulation and importance of terrestrial carbon in arctic coastal food webs. Progress in Oceanography 71: 362-378.

Fedorova, I., A. Chetverova, D. Bolshiyanov, A. Makarov, J. Boike, B. Heim, A. Morgenstern, P.P. Overduin, et al. 2015. Lena Delta hydrology and geochemistry: Long-term hydrological data and recent field observations. Biogeosciences 12: 345-363.

Frey, K.E., and J.W. McClelland. 2009. Impacts of permafrost degradation on arctic river biogeochemistry. Hydrological Processes 23: 169-182.

Fuchs, M., I. Nitze, J. Strauss, F. Günther, S. Wetterich, A. Kizyakov, M. Fritz, T. Opel, et al. 2020. Rapid fluvio-thermal erosion of a yedoma permafrost cliff in the Lena River Delta. Frontiers in Earth Science. https://doi.org/10.3389/feart.2020.00336.

Fuchs, M., J. Palmtag, B. Juhls, P.P. Overduin, G. Grosse, A. Abdelwahab, M. Bedington, T. Sanders, et al. 2021. Highresolution bathymetry models for the Lena Delta and Kolyma Gulf coastal zones. Earth System Science Data. https://doi.org/ 10.5194/essd-2021-256.

Günther, F., P.P. Overduin, A.V. Sandakov, G. Grosse, and M.N. Grigoriev. 2013. Short-and long-term thermo-erosion of ice-rich permafrost coasts in the Laptev Sea region. Biogeosciences 10: $4297-4318$.

Harden, J.W., C.D. Koven, C.-L. Ping, G. Hugelius, A. David McGuire, P. Camill, T. Jorgenson, P. Kuhry, et al. 2012. Field information links permafrost carbon to physical vulnerabilities of thawing. Geophysical Research Letters 39: L15704.

Harms, T.K., and J.B. Jones. 2012. Thaw depth determines reaction and transport of inorganic nitrogen in valley bottom permafrost soils. Global Change Biology 18: 2958-2968.

Hawkings, J.R., J.L. Wadham, L.G. Benning, K.R. Hendry, M. Tranter, A. Tedstone, P. Nienow, and R. Raiswell. 2017. Ice sheets as a missing source of silica to the polar oceans. Nature Communications 8: 14198.

Heikoop, J.M., H.M. Throckmorton, B.D. Newman, G.B. Perkins, C.M. Iversen, T. Roy Chowdhury, V. Romanovsky, D.E. Graham, et al. 2015. Isotopic identification of soil and permafrost nitrate sources in an Arctic tundra ecosystem. Journal of Geophysical Research: Biogeosciences 120: $1000-1017$.

Hobbie, J., G.R. Shaver, T.T. Høge, and J. Bowden. 2021. Artic Tundra. In Arctic Ecology, ed. D. Thomas. New York: Wiley.

Holmes, R.M., J.W. McClelland, B.J. Peterson, S.E. Tank, E. Bulygina, T.I. Eglinton, V.V. Gordeev, T.Y. Gurtovaya, et al. 2012. Seasonal and annual fluxes of nutrients and organic matter from large rivers to the Arctic Ocean and surrounding seas. Estuaries and Coasts 35: 369-382.

Holmes, R.M., J.W. McClelland, S.E. Tank, R.G.M. Spencer, and A.I. Shiklomanov. 2021. Arctic great rivers observatory. Water quality dataset, version 20210421. https://www. arcticgreatrivers.org/data.

Horn, M.A., and S.A. Hetz. 2021. Microbial nitrogen cycling in permafrost soils: implications for atmospheric chemistry. In Microbial Life in the Cryosphere and its Feedback on Global Change, ed. S. Liebner and L. Ganzert, 53-112. Berlin: De Gruyter.

Hugelius, G., J. Loisel, S. Chadburn, R.B. Jackson, M. Jones, G. MacDonald, M. Marushchak, D. Olefeldt, et al. 2020. Large stocks of peatland carbon and nitrogen are vulnerable to 
permafrost thaw. Proceedings of the National Academy of Sciences 117: 20438-20446.

Hugelius, G., J. Strauss, S. Zubrzycki, J.W. Harden, E. Schuur, C.-L. Ping, L. Schirrmeister, G. Grosse, et al. 2014. Estimated stocks of circumpolar permafrost carbon with quantified uncertainty ranges and identified data gaps. Biogeosciences 11: 6573-6593.

Juhls, B., C.A. Stedmon, A. Morgenstern, H. Meyer, J. Hölemann, B. Heim, V. Povazhnyi, and P.P. Overduin. 2020. Identifying drivers of seasonality in Lena River biogeochemistry and dissolved organic matter fluxes. Frontiers in Environmental Science 8: 53.

Kanevskiy, M., Y. Shur, J. Strauss, T. Jorgenson, D. Fortier, E. Stephani, and A. Vasiliev. 2016. Patterns and rates of riverbank erosion involving ice-rich permafrost (yedoma) in northern Alaska. Geomorphology 253: 370-384.

Kattner, G., J. Lobbes, H. Fitznar, R. Engbrodt, E.-M. Nöthig, and R. Lara. 1999. Tracing dissolved organic substances and nutrients from the Lena River through Laptev Sea (Arctic). Marine Chemistry 65: 25-39.

Kendall, C. 1998. Tracing nitrogen sources and cycles in catchments. In Isotope Tracers in Catchment Hydrology, ed. C. Kendall and J.J. McDonnell, 519-576. Amsterdam: Elsevier.

Kutzbach, L., D. Wagner, and E.-M. Pfeiffer. 2004. Effect of microrelief and vegetation on methane emission from wet polygonal tundra, Lena Delta, Northern Siberia. Biogeochemistry 69: 341-362.

Le Fouest, V., M. Manizza, B. Tremblay, and M. Babin. 2015. Modelling the impact of riverine DON removal by marine bacterioplankton on primary production in the Arctic Ocean. Biogeosciences 12: 3385-3402.

Lenton, T.M., J. Rockström, O. Gaffney, S. Rahmstorf, K. Richardson, W. Steffen, and H.J. Schellnhuber. 2019. Climate tipping points - too risky to bet against. Nature 575: 592-595.

Lewis, K., G. Van Dijken, and K.R. Arrigo. 2020. Changes in phytoplankton concentration now drive increased Arctic Ocean primary production. Science 369: 198-202.

Marushchak, M., A. Pitkämäki, H. Koponen, C. Biasi, M. Seppälä, and P. Martikainen. 2011. Hot spots for nitrous oxide emissions found in different types of permafrost peatlands. Global Change Biology 17: 2601-2614.

Marzadri, A., G. Amatulli, D. Tonina, A. Bellin, L.Q. Shen, G.H. Allen, and P.A. Raymond. 2021. Global riverine nitrous oxide emissions: The role of small streams and large rivers. Science of The Total Environment 776: 145148.

Mishra, U., G. Hugelius, E. Shelef, Y. Yang, J. Strauss, A. Lupachev, J.W. Harden, J.D. Jastrow, et al. 2021. Spatial heterogeneity and environmental predictors of permafrost region soil organic carbon stocks. Science advances 7: eaaz5236.

Overland, J.E., and M. Wang. 2013. When will the summer Arctic be nearly sea ice free? Geophysical Research Letters 40: 2097-2101.

Pastor, A., S. Poblador, L.J. Skovsholt, and T. Riis. 2020. Microbial carbon and nitrogen processes in high-Arctic riparian soils. Permafrost and Periglacial Processes 31: 223-236.

Rachold, V., A. Alabyan, H.W. Hubberten, V. Korotaev, and A. Zaitsev. 1996. Sediment transport to the Laptev Sea-hydrology and geochemistry of the Lena River. Polar Research 15: 183-196.

Rasmussen, L.H., A. Michelsen, P. Ladegaard-Pedersen, C.S. Nielsen, and B. Elberling. 2020. Arctic soil water chemistry in dry and wet tundra subject to snow addition, summer warming and herbivory simulation. Soil Biology and Biochemistry 141: 107676.

Reyes, F.R., and V.L. Lougheed. 2015. Rapid nutrient release from permafrost thaw in arctic aquatic ecosystems. Arctic, Antarctic, and Alpine Research 47: 35-48.
Sanders, T., C. Fiencke, J. Hüpeden, E.M. Pfeiffer, and E. Spieck. 2019. Cold adapted Nitrosospira sp: A potential crucial contributor of ammonia oxidation in cryosols of permafrost-affected landscapes in Northeast Siberia. Microorganisms 7: 699.

Sanders, T., C. Fiencke, and E.M. Pfeiffer. 2010. Small-scale variability of dissolved inorganic nitrogen (DIN), C/N rations and ammonia oxidizing capacities in various permafrost affected soils of Samoylov Island, Lena River Delta, Northeast Siberia. Polarforschung 80: 23-35.

Schade, J.D., E.C. Seybold, T. Drake, S. Spawn, W.V. Sobczak, K.E. Frey, R.M. Holmes, and N. Zimov. 2016. Variation in summer nitrogen and phosphorus uptake among Siberian headwater streams. Polar Research 35: 24571.

Schimel, J.P., and J. Bennett. 2004. Nitrogen mineralization: Challenges of a changing paradigm. Ecology 85: 591-602.

Seitzinger, S.P., and C. Kroeze. 1998. Global distribution of nitrous oxide production and $\mathrm{N}$ inputs in freshwater and coastal marine ecosystems. Global Biogeochemical Cycles 12: 93-113.

Shaver, G., F. Chapin III., and B.L. Gartner. 1986. Factors limiting seasonal growth and peak biomass accumulation in Eriophorum vaginatum in Alaskan tussock tundra. The Journal of Ecology 74: 257-278.

Shiklomanov, A.I., R.M. Holmes, J.W. McClelland, S.E. Tank, and R.G.M. Spencer. 2021. Arctic Great Rivers Observatory. Discharge Dataset, Version 20210319. https://www.arcticrivers. org/data.

Smith, D.M., J.A. Screen, C. Deser, J. Cohen, J.C. Fyfe, J. GarcíaSerrano, T. Jung, V. Kattsov, et al. 2019. The polar amplification model intercomparison project (PAMIP) contribution to CMIP6: Investigating the causes and consequences of polar amplification. Geoscientific Model Development 12: 1139-1164.

Smith, S.V., R.W. Buddemeier, F. Wulff, and D.P. Swaney. 2005. C, N. P fluxes in the coastal zone. In Coastal Fluxes in the Anthropocene, ed. C.J. Crossland, H.H. Kremer, H.J. Lindeboom, J.I. Marshall Crossland, and M.D.A. Le Tisser, 95-141. Berlin: Springer.

Stark, S., and M.-M. Kytöviita. 2006. Simulated grazer effects on microbial respiration in a subarctic meadow: Implications for nutrient competition between plants and soil microorganisms. Applied Soil Ecology 31: 20-31.

Steffen, W., A. Persson, L. Deutsch, J. Zalasiewicz, M. Williams, K. Richardson, C. Crumley, P. Crutzen, et al. 2011. The anthropocene: From global change to planetary stewardship. Ambio 40: 739.

Stewart, K.J., P. Grogan, D.S. Coxson, and S.D. Siciliano. 2014. Topography as a key factor driving atmospheric nitrogen exchanges in arctic terrestrial ecosystems. Soil Biology and Biochemistry 70: 96-112.

Tank, S.E., M. Manizza, R.M. Holmes, J.W. McClelland, and B.J. Peterson. 2012. The processing and impact of dissolved riverine nitrogen in the Arctic Ocean. Estuaries and Coasts 35: 401-415.

Terhaar, J., R. Lauerwald, P. Regnier, N. Gruber, and L. Bopp. 2021. Around one third of current Arctic Ocean primary production sustained by rivers and coastal erosion. Nature Communications 12: $1-10$.

Thibodeau, B., D. Bauch, and M. Voss. 2017. Nitrogen dynamic in Eurasian coastal Arctic ecosystem: Insight from nitrogen isotope. Global Biogeochemical Cycles 31: 836-849.

Tuerena, R.E., C. Mahaffey, S.F. Henley, C. de la Vega, L. Norman, T. Brand, T. Sanders, M. Debyser, et al. 2022. Nutrient pathways and their susceptibility to past and future change in the Eurasian Arctic Ocean. Ambio. https://doi.org/10.1007/s13280-02101673-0.

Voigt, C., M.E. Marushchak, B.W. Abbott, C. Biasi, B. Elberling, S.D. Siciliano, O. Sonnentag, K.J. Stewart, et al. 2020. Nitrous 
oxide emissions from permafrost-affected soils. Nature Reviews Earth \& Environment 1: 420-434.

Weintraub, M.N., and J.P. Schimel. 2003. Interactions between carbon and nitrogen mineralization and soil organic matter chemistry in arctic tundra soils. Ecosystems 6: 129-143.

Wheeler, P.A., B.B. North, and G.C. Stephens. 1974. Amino acid uptake by marine phytoplankters 1, 2. Limnology and Oceanography 19: 249-259.

Wild, B., A. Andersson, L. Bröder, J. Vonk, G. Hugelius, J.W. McClelland, W. Song, P.A. Raymond, et al. 2019. Rivers across the Siberian Arctic unearth the patterns of carbon release from thawing permafrost. Proceedings of the National Academy of Sciences 116: 10280-10285.

Zubrzycki, S., L. Kutzbach, G. Grosse, A. Desyatkin, and E.M. Pfeiffer. 2013. Organic carbon and total nitrogen stocks in soils of the Lena River Delta. Biogeosciences 10: 3507-3524.

Publisher's Note Springer Nature remains neutral with regard to jurisdictional claims in published maps and institutional affiliations.

\section{AUTHOR BIOGRAPHIES}

Tina Sanders $(\bowtie)$ is a Senior Scientist at the Helmholtz-Zentrum Hereon. Her research interests include aquatic nutrient cycles and nitrogen stable isotopes.

Address: Institute for Carbon Cycles, Helmholtz-Zentrum Hereon, Geesthacht, Germany.

e-mail: tina.sanders@hereon.de

Claudia Fiencke is Senior Scientist at the University of Hamburg, Institute of Soil Science. Her research interests include microbial terrestrial nitrogen turnover with focus on nitrification, ecological soil evaluation.

Address: Institute of Soil Science, Universität Hamburg, AllendePlatz 2, 20146 Hamburg, Germany.

Address: Center for Earth System Research and Sustainability, Universität Hamburg, Allende-Platz 2, 20146 Hamburg, Germany.

e-mail: Claudia.Fiencke@uni-hamburg.de

Matthias Fuchs is a PostDoc at the Alfred Wegener Institute Helmholtz Centre for Polar and Marine Research, Potsdam, Germany. His research interests include permafrost research, biogeochemistry, arctic coastal wetlands.

Address: Permafrost Research Section, Helmholtz Centre for Polar and Marine Research, Alfred Wegener Institute, Telegrafenberg A 45, Potsdam, Germany.

e-mail: matthias.fuchs@awi.de

Charlotte Haugk is a Doctoral candidate at the Stockholm University. Her research interest include the organic matter release from permafrost-affected soils

Address: Department of Environmental Science and Analytical Chemistry, Stockholm University, Svante Arrhenius Väg 8, 11418 Stockholm, Sweden.

e-mail: charlotte.haugk@aces.su.se

Bennet Juhls is a Postdoc at the Alfred Wegener Institute Helmholtz Centre for Polar and Marine Research. His research interests include land-ocean matter fluxes in the Arctic, aquatic biogeochemisty, and optical and radar remote sensing.

Address: Permafrost Research Section, Helmholtz Centre for Polar and Marine Research, Alfred Wegener Institute, Telegrafenberg A 45, Potsdam, Germany.

e-mail: bjuhls@awi.de
Gesine Mollenhauer is a marine organic geochemist at the Alfred Wegener Institute in Bremerhaven, Germany. She uses a combination of organic geochemical methods and radiocarbon dating to investigate transport of organic matter and carbon cycling in a land-ocean continuum, the fate of terrestrial organic matter delivered to aquatic systems and the ocean, and glacial-interglacial changes in these processes.

Address: Marine Geochemistry Section, Helmholtz Centre for Polar and Marine Research, Alfred Wegener Institute, Am Handelshafen 12, 27570 Bremerhaven, Germany.

e-mail: Gesine.mollenhauer@awi.de

Olga Ogneva is a Doctoral Candidate at the Alfred Wegener Institute in Bremerhaven, Germany. Her research interest include investigation of stable composition of organic carbon.

Address: Marine Geochemistry Section, Helmholtz Centre for Polar and Marine Research, Alfred Wegener Institute, Am Handelshafen 12, 27570 Bremerhaven, Germany.

e-mail: Olga.Ogneva@awi.de

Paul Overduin studies permafrost as a Senior Scientist at the Alfred Wegener Institute Helmholtz Centre for Polar and Marine Research in Potsdam, Germany. He focusses especially on permafrost beneath the Arctic shelf seas and on interaction between permafrost and surface waters.

Address: Permafrost Research Section, Helmholtz Centre for Polar and Marine Research, Alfred Wegener Institute, Telegrafenberg A 45, Potsdam, Germany.

e-mail: Paul.Overduin@awi.de

Juri Palmtag is a Research Fellow at the Department of Geography and Environmental Sciences at Northumbria University. His research interests range from the spatial distribution of terrestrial soil organic carbon and nitrogen in permafrost-affected soils to carbon dioxide and methane fluxes from nearshore environments.

Address: Department of Geography and Environmental Sciences, Northumbria University, Newcastle-upon-Tyne NE1 8ST, UK.

e-mail: juri.palmtag@northumbria.ac.uk

Vasily Povazhniy is a Co-Head of German-Russian Otto-Schmidt Laboratory for Polar and Marine Research in Arctic and Antarctic Research Institute. $\mathrm{He}$ is a water ecologist and biogeochemist, studying nutrients and carbon cycling in Siberian Shelf Seas and Lena River delta.

Address: Otto Schmidt Laboratory for Polar and Marine Research, Arctic and Antarctic Research Institute, Beringa 38, Saint Petersburg,

Russia 199397.

e-mail: povazhny@aari.ru

Jens Strauss is a Geoecologist who heads the working group on Permafrost Biogeochemistry of the Permafrost Research Section at the Alfred Wegener Institute (AWI) in Potsdam. He has specialized in deep ice-rich permafrost (Yedoma) and his research strives to determine the size of the organic carbon pool frozen in Yedoma, the quality of this carbon, and the speed at which it may be broken down by microorganisms and released in the form of greenhouse gases if it thaws.

Address: Permafrost Research Section, Helmholtz Centre for Polar and Marine Research, Alfred Wegener Institute, Telegrafenberg A 45,

Potsdam, Germany.

e-mail: jens.strauss@awi.de

Robyn Tuerena is a Lecturer in Nutrient Biogeochemistry at the Scottish Association for Marine Science. Her research interests include carbon and nutrient cycling in open ocean and Arctic environments. 
Address: Scottish Association for Marine Science, Dunstaffnage, Oban PA37 1QA, UK.

e-mail: robyn.tuerena@sams.ac.uk

Nadine Zell is Master Student at the University of Hamburg. Her master thesis investigate the nitrogen turn-over in Cryosols.

Address: Institute of Soil Science, Universität Hamburg, AllendePlatz 2, 20146 Hamburg, Germany.

Address: Center for Earth System Research and Sustainability, Universität Hamburg, Allende-Platz 2, 20146 Hamburg, Germany.

e-mail: Nadine.zell@uni-hamburg.de
Kirstin Dähnke is Head of the Department for Aquatic nutrient cycles in the institute of Carbon Cycles at Helmholtz Zentrum Hereon. Her research interests include coastal and marine nutrient cycles and stable isotope applications.

Address: Institute for Carbon Cycles, Helmholtz-Zentrum Hereon, Geesthacht, Germany.

e-mail: kirstin.daehnke@hereon.de 